\title{
1 A comparative study of flexibility in water \\ 2 allocation in the context of hydrologic \\ 3 variability
}

$4 \quad$ Hang Zheng ${ }^{1}$, Clive Lyle ${ }^{2}$, Zhongjing Wang ${ }^{3}$

51 Lecturer, State Key Laboratory of Hydro-Science and Engineering, Department

6 of Hydraulic and Hydropower Engineering, Tsinghua University, Beijing, 10084,

7 CHINA.

8 E-mail: zhenghang@ tsinghua.edu.cn

9 Phone: (86)13810668746

10 Fax: (86)10 67296971

112 Principal Research Fellow, Australia-China Water Resource Research Center,

12 the University of Melbourne, Melbourne, Victoria, 3010, AUSTRALIA.

13 E-mail: cwlyle@gmail.com

14 Phone: (61) 398163957

15 Fax: (86)10 67296971

163 Professor, State Key Laboratory of Hydro-Science and Engineering,

17 Department of Hydraulic and Hydropower Engineering, Tsinghua University,

18 Beijing, 10084, CHINA.

19 E-mail: zj.wang@tsinghua.edu.cn

20 Phone: (86)13501076319

21 Fax: (86)10 67296971

22 Abstract: River flow that is characterized by variability requires commensurate

23 flexibility in allocating water so that water users are able to plan their activities

24 and respond accordingly. An indicator-based assessment method is proposed in

25 this study to evaluate the flexibility of water allocation, based on a concept that a

26 flexible water allocation regime provides greater opportunity for users to freely

27 decide individual water use and leads to more variability and diversity for water

28 consumption among the users. This is demonstrated by using historical water-use

29 data and applying the assessment method in three river basins with different water

30 allocation regimes. These allocation regimes include the seasonal and volumetric

31 water allocation system in the Yellow River of China, duration-based water

32 allocation in Northwestern China, and capacity sharing in southern Queensland in

33 the northern Murray Darling Basin of Australia. Historical water-use variability

34 and diversity are defined and assessed. The result shows that water allocation

35 flexibility varies across the different water entitlement regimes. Duration-based 
water allocation, a type of allocation that provides the highest degree of water-use

37 autonomy, is ranked as the most flexible regime. Seasonal water allocation, which

38 has the highest level of centralized regulation, shows the lowest flexibility. The

39 proposed indicator based assessment method would be useful for evaluating the

40 flexibility of policy options for water allocation. This could be helpful for

41 improving the capability of water allocation regimes to cope with the changing

42 environment and improving the effectiveness of water allocation systems.

43 Key words: water allocation; flexibility; autonomy; assessment.

\section{Introduction}

45 Overexploitation of water resources, degradation of river ecosystems, and an

46 increasing number of social conflicts following the unsustainable use of water

47 resources demonstrate the wide gap between the objectives of sustainability and

48 current resource management practices. The management of water resources is a

49 particularly challenging and difficult task, facing continual variability and

50 uncertainty in the availability of water resources posed by climate change

51 (Graddon et al. 2011).

52 Conventional water supply systems have been traditionally designed in fixed and

53 rigid patterns (Cross 2000). Such designs have led to a supply management that

54 could be easily and simply controlled but with less capacity to accommodate

55 uncertainty and environmental change. A water resource system should be a

56 hybrid dynamic system that can be subjected to continuous operations broken by

57 discrete events when new goals can be defined in the short-term, either to

58 guarantee an efficient use of the upstream water reserves or to enforce security

59 (Faye et al. 2005).

60 Literature on issues pertaining to flexibility of water resource management has

61 proliferated in recent years. (Grönlund and Määttä 2008; Falkenmark and

62 Rockström 2010; Li and Chang 2011; Teh et al. 2012; Jafarzadegan et al. 2013)

63 Widespread interest in this topic emphasizes the importance of understanding

64 water resource management flexibility. The word "flexible" is used in the English

65 language to describe objects "capable of responding or conforming to changing or

66 new situations". Flexibility is therefore the property that makes an object

67 "flexible" (Gupta and Buzacott 1989). Water resource systems are argued to be 
68 more flexible in the short run as they are able to adjust supply quantities to 69 unexpected demands or inflow changes. Flexibility adds great value to a system 70 because of the advantage of providing the supply process with the ability to 71 modify itself under uncertainty (Marreco and Carpio 2006).

72 According to Cross (2000), flexibility in water supplies enables the informed 73 farmer to choose almost any means of on-farm irrigation practice that best meets 74 the needs of the desired crop, the cost and availability of labor, and other local 75 economic or social situations.. Schlüter and Pahl-Wostl (2007) reported that the 76 diversification of resource use increases the resilience of resource management 77 under the given conditions of a regularly fluctuating inflow. These studies 78 demonstrated that water management flexibility could be enabled by increasing 79 the autonomy and diversity of choices for water users. Numerous water resource 80 management practices for establishing autonomous, self-adaptive, and thus, 81 flexible water governance systems include bottom-to-top decision making 82 systems, water users associations, and water markets (Zheng et al. 2012).

83 Nevertheless, inherent constraints against flexibility in water allocation remain 84 because of competition for water-use brought about by a conventional centralized 85 and bureaucratic management system. Substantial gaps still remain in our 86 knowledge about flexibility in a water-allocation regime, as well as identifying, 87 measuring, and improving it to cope with the changing environment. Related 88 research studies are rare, especially on quantitative methods.

89 This paper proposes a quantitative method to evaluate the flexibility of water 90 allocation regimes in the context of hydrologic variability. The method measures 91 water allocation flexibility through assessing the performance of the allocation 92 regime in promoting variable and diverse water-use among water consumers. If 93 greater variability and diversity of individual water-use are observed under a 94 water allocation regime in a river basin, it follows that there are more autonomy in 95 water use and higher flexibility in water allocation. This concept and method are 96 applied in three different water allocation regimes in China and in Australia. The 97 proposed method is helpful in providing insights on the flexibility of water 98 allocation regimes and valuable to facilitate the institutions' consideration on 99 improving the performance of allocation systems. 


\section{Method}

$101 \quad 2.1$ Concept

102 A concept of flexible water allocation is argued in this study, which is that

103 flexible water allocation provides more water use autonomy and leads to greater

104 variability and diversity of water use among consumers. This concept is

105 established based on literature review. Several arguments for increasing the

106 flexibility of water resources management are catalogued into two groups. The

107 first argues that flexibility in water resources management can be increased by

108 providing water authorities with diversity, real time and optimal solutions as much

109 as possible to assist them in adapting to every possible condition under changing

110 conditions of water availability (Larsen and Gujer 2001; Faye et al. 2005;

111 Marreco and Carpio 2006; Milman and Short 2008; Li and Chang 2011). This can

112 be seen as the "top to bottom" method. The second argues that flexible water

113 resources management can be achieved by providing more opportunities or

114 autonomy to water users so they can choose the solutions that best meet their

115 needs (Gunderson et al. 2006; Wright et al. 2010; Assche et al. 2012; Teh et al.

116 2012). This is recognized as the "bottom to top" method.

117 Due to the inevitable uncertainty and complexity in the real world, providing

118 overall flexible solutions to cope with every possible condition is costly and

119 requires a flexible user community. Water governance authorities are increasingly

120 delegating the power to water users and gain management simplicity and low

121 administrative costs. Water allocation flexibility under the "bottom to top"

122 concept is adopted in the study.

\section{$123 \quad 2.2$ The quantitative assessment approach}

124 The entropy model which is the suggested as a tool to measure the flexibility 125 (Kumar 1987; Shuiabia et al. 2005) is adopted in this study. The model considers

126 the size of the set of choices available subsequent to any decision as a measure of 127 the inherent flexibility of the decision. A higher number of choices provide 128 greater flexibility. This concept is interestingly captured by "entropy".

129 In water management systems, water allocation regime interventions are in the 130 form of regulations that change and regulate water users' access to the available 
131 water resource. How water users respond to regulations, such as the consumers'

132 ability and freedom to use water is influenced by the size of the set of choices

133 available, which reflects the flexibility of a water allocation regime. Higher

134 variability and diversity in water consumption among different water users means

135 more "entropy" in the water management system and reflects greater flexibility in

136 the allocation system. The historical variability and spatial diversity data of water

137 use in a river basin under a certain water allocation regime are adopted in this

138 study to measure water allocation flexibility.

139 The method framework is illustrated in Fig. 1. The water availability in a river

140 basin varies with time because of runoff variability. The runoff is allocated to 141 water users according to certain allocation regimes. The water allotment 142 represents the water use ration in a given hydrologic condition. The water use 143 ration can be identified through several approaches, such as a volumetric cap for 144 water withdrawal.

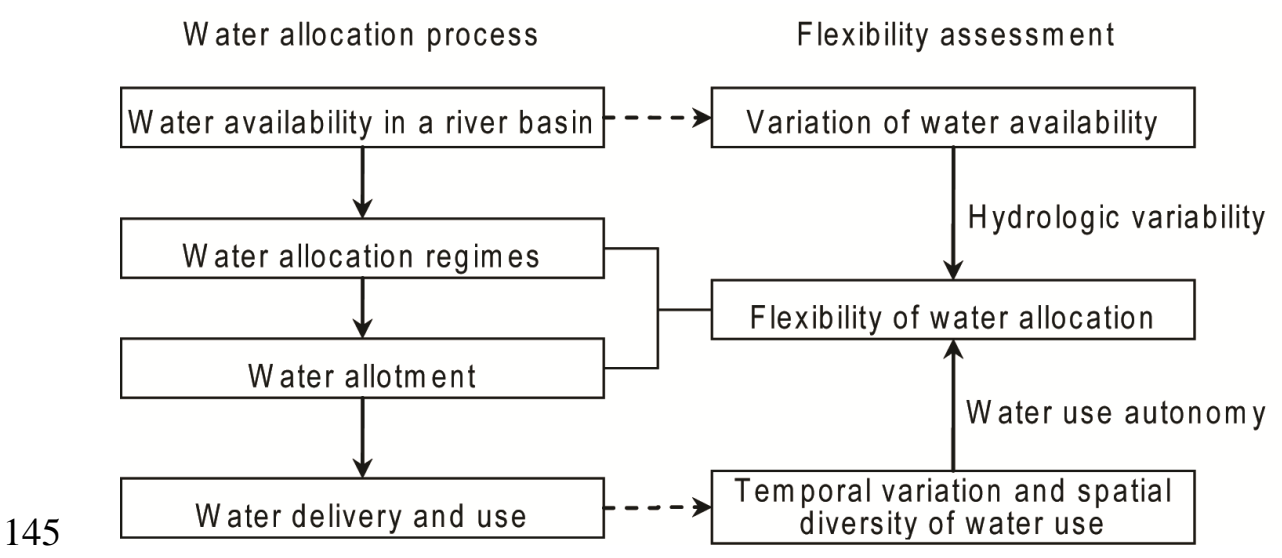

146 Fig.1 Framework for flexibility assessment on surface water allocation 147 regimes

148 A flexibility indicator is proposed in this study according to the framework, as 149 shown in Equation (1).

$$
\left.\left.F=\frac{C \Psi W(t)]}{C \Psi W(t)]} \cdot C_{i} Y C_{t} \Psi W \psi(t)\right]\right]
$$

151 where, $\boldsymbol{t}$ is the time step, e.g., year; $\boldsymbol{C V}()$ is the coefficient of variation, which is 152 defined as the ratio of the standard deviation to the mean; $\boldsymbol{W U}()$ is the surface 153 water use in the river basin; $\boldsymbol{W A}()$ represents the surface water availability in the 154 basin; $\boldsymbol{W} \boldsymbol{U}_{\mathrm{i}}()$ is the surface water use of water users $\boldsymbol{i} ; \boldsymbol{i}$ is the order of the water 155 users; $\boldsymbol{F}$ is the indicator of flexibility; $\boldsymbol{C} \boldsymbol{V}[\boldsymbol{W U}(\boldsymbol{t})] / \boldsymbol{C} \boldsymbol{V}[\boldsymbol{W A}(\boldsymbol{t})]$ represents the 
156 variation in water use in the basin per unit change of water availability;

$157 \boldsymbol{C} \boldsymbol{V}_{\mathrm{t}}\left[\boldsymbol{W} \boldsymbol{U}_{\mathrm{i}}(t)\right]$ reflects the water use variability of water user $\boldsymbol{i}$; and

$158 \boldsymbol{C} \boldsymbol{V}_{\mathrm{i}}\left[\boldsymbol{C} \boldsymbol{V}_{\mathrm{t}}\left[\boldsymbol{W} \boldsymbol{U}_{\mathrm{i}}(\boldsymbol{t})\right]\right]$ represents water-use diversity across all the water users.

159 Multiplication is adopted to integrate the water-use variations and diversity to

160 form the indicator $\boldsymbol{F}$ of water allocation flexibility. Higher variability and

161 diversity of water use in the basin results in a larger indicator $\boldsymbol{F}$, and represents

162 greater flexibility.

\section{$163 \quad 2.3$ The study areas}

164 Three river basins in China and Australia are adopted as case study areas, 165 including the Yellow River Basin (Yellow RB) in China with Seasonal Water 166 Allocation (SWA), the St. George region of Queensland of the Murray-Darling

167 Basin in Australia with Capacity Sharing (CS) regime, and the Taolai River Basin

168 (Taolai RB) in Northwestern China with Duration-based Water Allocation 169 (DWA).

170 Generally, a water-use ration is set for each water user in the water allocation 171 process (Wang et al. 2009; Zheng et al. 2011) to ensure that total water use will

172 not exceed the water availability of the basin. In SWA, water is allocated as shares

173 of the total volume of water releases in a given season. The water that the regions

174 have rights to use is then intended to be limited to their allocated seasonal water

175 volume. CS regime proposes a system of allocating water property rights to a 176 share of the total storage (and hence a share of inflows and losses) which has been 177 established in Australia (Dudley and Musgrave 1988; Hughes and Goesch 2009a).

178 In this system, each user is allocated a share of the total system storage capacity 179 and a share of total inflows and losses (i.e., evaporation and seepage). Users 180 independently manage their capacity shares, including carrying over unused water 181 between years in the reservoirs according to pre-defined rules. Duration-based 182 water allocation originated from a traditional Chinese water allocation system 183 about 200 years ago during the Qing dynasty. In the 18th century, an 184 administrative water allocation system was established in some arid rivers of 185 Northwestern China, in which the water extraction times of upstream and 186 downstream users were defined by the river basin authority. This system is still 187 being implemented in the Taolai RB. Instead of sharing the seasonal water release 188 volume or storage capacity, water is allocated based on the duration or time. Each 
189 water user in the river basin is allocated a share of the total number of water

190 release days within a year, during which they can take water from the river freely

191 without volumetric or other controls. This type of water allocation is denoted

192 'duration-based water allocation' in this paper.

\section{2.3.1 Yellow River in China and seasonal water allocation}

194 Yellow River, the second largest river in China, originates from the Tibetan

195 Plateau, wanders through the northern semi-arid region, crosses the Loess Plateau,

196 passes through the Eastern Plain, and finally discharges into the Bohai Gulf (Fig.

197 2). The main course of the river flows approximately $5,500 \mathrm{~km}$ in distance and 198 accumulates $753,000 \mathrm{~km}^{2}$ of drainage area. Approximately 100 million people 199 live within the basin. (Shao et al. 2009).

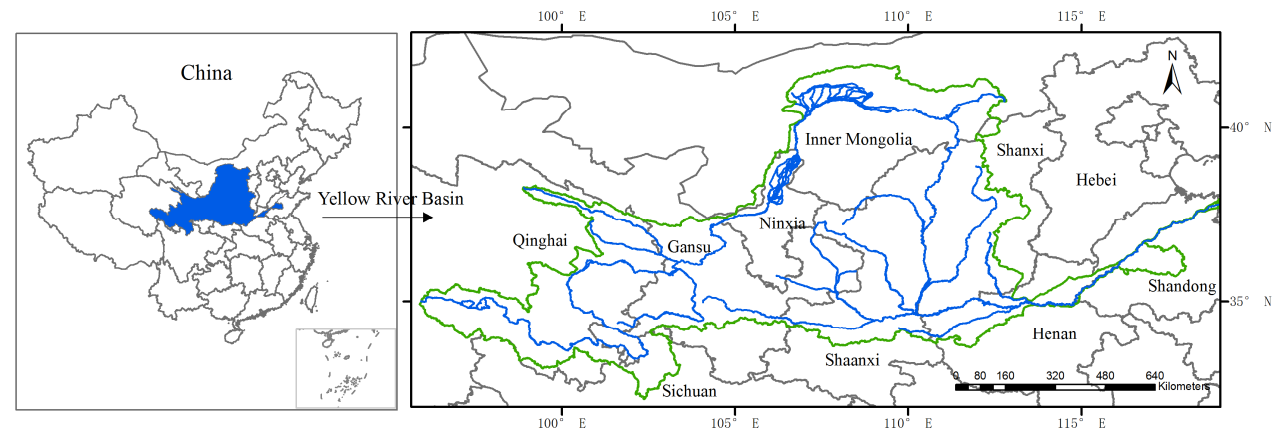

201 Fig. 2 the Yellow River basin and the riparian provinces (municipalities)

202 Note: Data from the National Fundamental Geographic Information System, 203 China.

204 In 1987, the "Yellow River water allocation scheme" was approved by the

205 Chinese State Council. The scheme proposed a sharing of water use entitlement 206 among all riparian provinces and the ecosystem. The long-term mean annual 207 natural runoff of 58,000 million $\mathrm{m}^{3}$ was divided into two parts: 37,000 million $\mathrm{m}^{3}$ 208 as the maximum water supply capacity for human use (Table 1) and 21,000 209 million $\mathrm{m}^{3}$ for in-stream sediment flushing (YRCC 2008).

210 Table 1 Annual mean water entitlement sharing in the Yellow River (Unit: $10^{8}$ $\left.211 \mathrm{~m}^{3}\right)$

\begin{tabular}{cccccccccccc}
\hline Province & \multicolumn{4}{c}{ Qinghai Sichuan Gansu Ningxia } & \multicolumn{3}{c}{$\begin{array}{c}\text { Inner } \\
\text { Mongolia }\end{array}$} & \multicolumn{3}{c}{ Shaanxi Shanxi Henan Shandong Tianjin Total } \\
\hline $\begin{array}{c}\text { Water } \\
\text { Entitlement }\end{array}$ & 14.1 & 0.4 & 30.4 & 40.0 & 58.6 & 38.0 & 43.1 & 55.4 & 70.0 & 20.0 & 370.0 \\
\hline
\end{tabular}


212 Note: Data from the "Yellow River water allocation scheme", Chinese State 213 Council, 1987.

214 In the 1990s, a SAW regime was established (Yang et al. 2004). At the end of 215 1998, the Chinese State Planning Commission and the Ministry of Water

216 Resources formulated the "Administrative Measures of Yellow River Water

217 Diversion", which stipulated the procedures of SAW in the Yellow River to 218 ensure the enforcement of the "1987 Scheme". Considering the variations 219 between different years and within each year, the Yellow River Conservation

220 Commission (YRCC) formulates an annual water diversion plan with detailed 221 monthly water allocation quota according to different natural runoff and storage 222 rates in the reservoirs (Xia and Pahl-Wostl 2012).

\section{2.3.2 St. George region in Australia and capacity sharing}

224 CS has been in operation in the St. George region of the Murray-Darling Basin in 225 Australia since 2000 and is being adopted elsewhere in the Basin.

226 The Murray-Darling Basin is Australia's largest and most important catchment, 227 covering one-seventh of the continent $\left(1\right.$ million $\left.\mathrm{km}^{2}\right)$; it is responsible for about 228 half the nation's food and agricultural production and supplies water to more than 229 two million people. St. George is located on the Balonne River in southern 230 Queensland and in the northern the Murray-Darling Basin (Fig. 3). The St. 231 George irrigation region covers a total area of around $190 \mathrm{~km}^{2}$. The main irrigated 232 crop in the region is cotton, but some grapes and vegetables are also produced. 233 The total surface water of the region is 99.5 million $\mathrm{m}^{3}$, of which the issued water 234 entitlement is 84.4 million $\mathrm{m}^{3}$. 


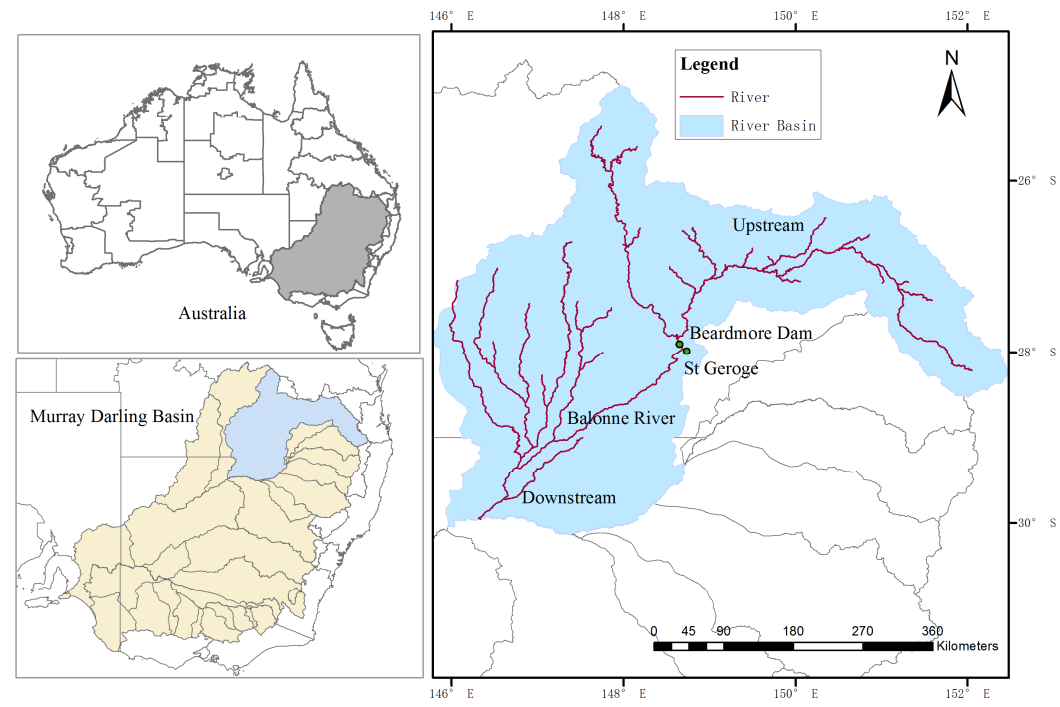

236 Fig. 3 the case location and the rivers of the St. George region

237 Note: Data from the Geoscience Australia, Australian Government

238 The main water storage in the St. George irrigation system is the Beardmore Dam,

239 which has a storage capacity of 81.7 million $\mathrm{m}^{3}$. In the CS, each capacity share

240 defines an equal and inseparable proportional share of inflows and storage. For

241 example, a $10 \%$ capacity share includes a right to $10 \%$ of the storage capacity and

242 a $10 \%$ share of available inflows. Approximately 80.7 million $\mathrm{m}^{3}$ of the system's

243 effective storage capacity is allocated to individual irrigators. Table 2 summarizes

244 the distribution of storage capacity shares in St. George.

245 Table 2 Storage shares, St. George (Unit: $10^{4} \mathrm{~m}^{3}$ )

\begin{tabular}{cccccc}
\hline $\begin{array}{l}\text { Size of Storage } \\
\text { Capacity Share }\end{array}$ & $<\mathbf{5}$ & $\mathbf{5}$ to $\mathbf{5 0}$ & $\mathbf{5 0 ~ t o 1 5 0}$ & $>\mathbf{1 5 0}$ & Total \\
\hline Number of Users & 18 & 25 & 29 & 22 & 94 \\
\hline
\end{tabular}

246 Note: Data from the Australian Bureau of Agricultural and Resource Economics,

2472009.

\subsubsection{Taolai River in China and duration-based water allocation}

249 The Taolai RB is an inland river basin located in Gansu Province of Northwestern

250 China covering an area of $28,100 \mathrm{~km}^{2}$. The total runoff in the mainstream of the 251 basin is 683 million $\mathrm{m}^{3}$ and the water storage is 232 million $\mathrm{m}^{3}$. There are three 252 main water users in the basin (Fig. 4) including the Jiuquan Iron \& Steel 253 Corporation (JQI\&SC), the Taolai Irrigation District (Taolai ID), and the 254 Yuanyang Irrigation District (Yuanyang ID). Using the DWA system, users share 255 the annual water release days (365 days in total) of the mainstream of the Taolai 
256 River: 37 days of water use for upstream JQI\&SC; 153 days for Taolai ID; and 257175 days for downstream Yuanyang ID. These days are referred to as "allocation 258 period" in this paper. Except for the annual water use of JQI\&SC that is limited to 25945 million $\mathrm{m}^{3}$, Taolai ID and Yuanyang ID can store or use the entire natural 260 stream flow during their water allocation period.
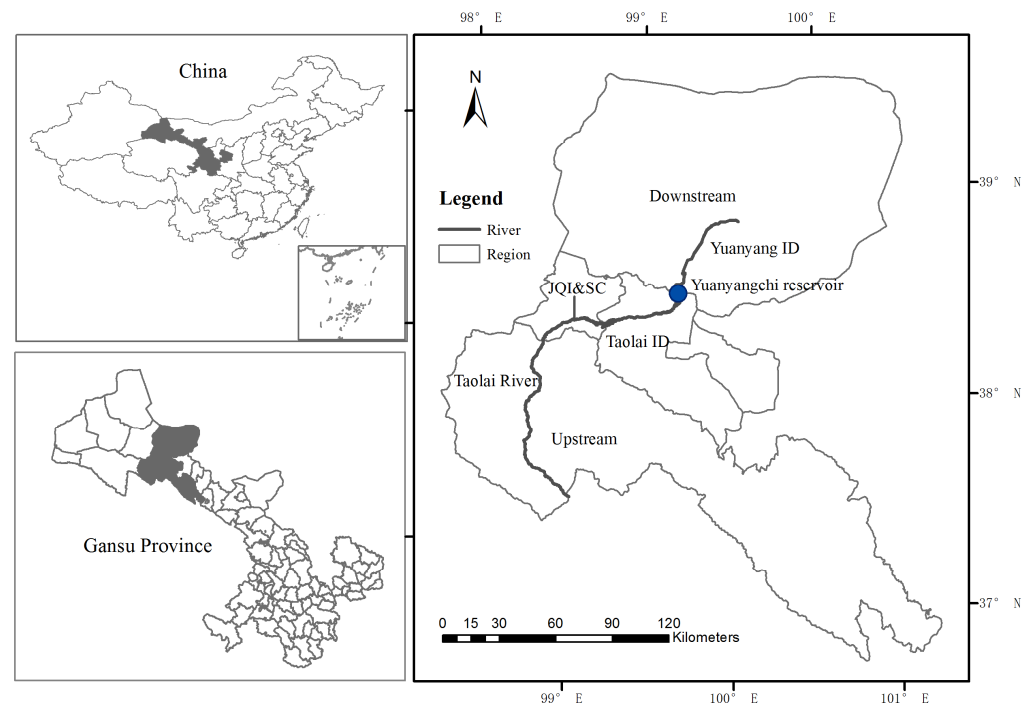

262 Fig. 4 Location and river of the Taolai Basin

263 Note: Data from the National Fundamental Geographic Information System, 264 China.

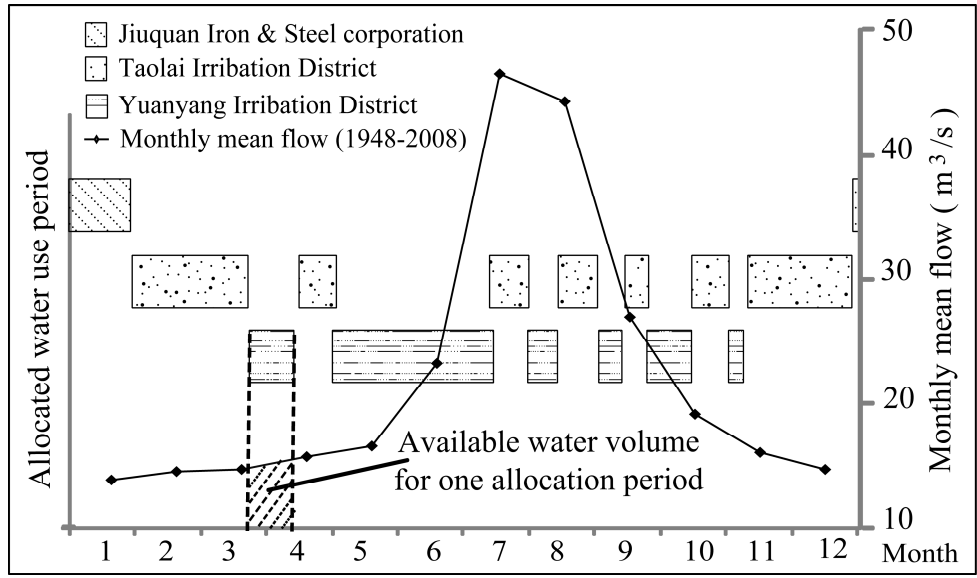

Fig. 5 Duration-based water allocation in the Taolai River Basin

267 Note: Data from the Water Resources Management Bureau of Taolai River Basin, 268 China.

269 Under the DWA system, the discharge volume within a specific allocation period 270 provides the maximum available water for the user who is authorized to withdraw 271 water during that period. As illustrated in Fig. 5, the shaded area under the flow 
272 curve indicates the available water volume for Yuanyang ID in its first allocation

273 period of the year. The annual available water can be identified by accumulating

274 all the available water in each allocation period within the year.

275 The main characters of three regions are shown in Table 3. The Yellow RB is 276 largest based on spatial area. In the Yellow RB, water is allocated to a few 277 provinces but there are a very large number of users across a great area. There are 2783 users in the Taolai RB and the reservoir storage capacity there is only $34 \%$ $279(=232 / 683)$ of the surface water resources. In St. George, the reservoirs can almost 280 store all the available surface water and the capacity sharing in the St. George is 281 carried by 94 users on a small area.

282 Table 3 the main characters of three basins/regions referring to the water 283 allocation regimes

\begin{tabular}{|c|c|c|c|c|c|}
\hline$\overline{\text { Basin/Region }}$ & $\begin{array}{l}\text { Area } \\
\left(\mathrm{km}^{2}\right)\end{array}$ & $\begin{array}{c}\text { Surface water } \\
\text { availability } \\
\left(\text { Million } \mathbf{m}^{3} / \mathbf{a}\right)\end{array}$ & $\begin{array}{c}\text { Storage } \\
\text { capacity } \\
\left(\text { Million } \mathbf{m}^{3} / \mathbf{a}\right)\end{array}$ & Allocation regimes & Users \\
\hline Yellow River & 753,000 & 58,000 & 30,340 & $\begin{array}{c}\text { Seasonal water } \\
\text { allocation }\end{array}$ & 10 provinces \\
\hline St. George & 190 & 84 & 100 & Capacity sharing & 94 users \\
\hline Taolai River & 28,100 & 683 & 232 & $\begin{array}{c}\text { Duration-based } \\
\text { allocation }\end{array}$ & 3 users \\
\hline
\end{tabular}

\section{$284 \quad 3$ Results}

285 As shown in Table 4, the coefficient of variation (CV) of annual natural runoff 286 and relevant water allotment in the Yellow RB is 0.20 . The social-economic water 287 allotment is presumed to have increased in the wet year, decreased in the dry year, 288 and varied in the same proportion with the changes of annual natural runoff. The 289 inter-year water that remained in the reservoirs does not contribute to the water 290 allotment when the water allotment is continuously accounted across multiple 291 years in this study. The CV of total water use in the basin is 0.09 , representing 292 low variability of water use in the Yellow River under the current seasonal water 293 allocation regime. The water-use CVs of the inner-basin provinces vary from 0.07 294 to 0.19 , across which the diversity of water use (identified as the variability of 295 individual water users' CVs) is 0.35 .

296 Table 4 annual water allotment and use in the Yellow River Basin (Unit: $10^{8} \mathrm{~m}^{3}$ )

\begin{tabular}{|c|c|c|c|c|c|c|c|c|c|c|c|c|}
\hline & & Natural & Annual water & & & & & Water us & & & & \\
\hline NO. & Year & $\begin{array}{c}\text { runoff } \\
\text { (1) }\end{array}$ & $\begin{array}{c}\text { allotment } \\
\text { (2) }\end{array}$ & $\begin{array}{c}\text { Qinghai } \\
\text { (3) }\end{array}$ & $\begin{array}{c}\text { Gansu } \\
(4)\end{array}$ & $\begin{array}{c}\text { Ningxia } \\
\text { (5) }\end{array}$ & $\begin{array}{c}\text { Inner } \\
(6)\end{array}$ & $\begin{array}{c}\text { Shaanxi } \\
\text { (7) }\end{array}$ & $\begin{array}{c}\text { Shanxi } \\
(8)\end{array}$ & $\begin{array}{c}\text { Henan } \\
(9)\end{array}$ & $\begin{array}{c}\text { Shandong } \\
(\mathbf{1 0})\end{array}$ & $\begin{array}{c}\text { Total } \\
(11)\end{array}$ \\
\hline (1) & 1988 & 560.3 & 349.6 & 13.4 & 25.7 & 42.5 & 63.3 & 22.1 & 12.1 & 50.8 & $\begin{array}{r}95.5 \\
11\end{array}$ & 325.3 \\
\hline
\end{tabular}




\begin{tabular}{|c|c|c|c|c|c|c|c|c|c|c|c|c|}
\hline NO. & Year & $\begin{array}{c}\text { Natural } \\
\text { runoff } \\
(1)\end{array}$ & $\begin{array}{l}\text { Annual water } \\
\text { allotment } \\
\text { (2) }\end{array}$ & $\begin{array}{c}\text { Qinghai } \\
\text { (3) }\end{array}$ & $\begin{array}{c}\text { Gansu } \\
\text { (4) }\end{array}$ & $\begin{array}{c}\text { Ningxia } \\
\text { (5) }\end{array}$ & $\begin{array}{c}\text { Inner } \\
(6)\end{array}$ & $\begin{array}{c}\text { Water us } \\
\text { Shaanxi } \\
\text { (7) }\end{array}$ & $\begin{array}{l}\text { Shanxi } \\
(8)\end{array}$ & $\begin{array}{c}\text { Henan } \\
(9)\end{array}$ & $\begin{array}{c}\text { Shandong } \\
\text { (10) }\end{array}$ & $\begin{array}{c}\text { Total } \\
\text { (11) }\end{array}$ \\
\hline (2) & 1989 & 688.7 & 337.7 & 9.8 & 23.3 & 34.1 & 60.6 & 19.6 & 14.4 & 37.2 & 134.8 & 333.8 \\
\hline (3) & 1990 & 507.6 & 415.1 & 10.0 & 23.6 & 35.4 & 64.6 & 18.5 & 12.3 & 33.0 & 80.9 & 278.3 \\
\hline (4) & 1991 & 392.0 & 306.0 & 15.9 & 23.9 & 34.6 & 71.6 & 19.7 & 12.5 & 40.0 & 83.2 & 301.3 \\
\hline (5) & 1992 & 519.8 & 236.3 & 15.8 & 24.5 & 33.7 & 66.2 & 21.0 & 13.2 & 33.8 & 89.3 & 297.5 \\
\hline (6) & 1993 & 529.2 & 313.3 & 9.9 & 21.1 & 31.7 & 67.9 & 17.3 & 10.3 & 35.5 & 86.1 & 279.8 \\
\hline (7) & 1994 & 445.6 & 319.0 & 10.6 & 17.6 & 31.6 & 63.5 & 22.8 & 9.2 & 28.8 & 71.1 & 255.3 \\
\hline (8) & 1995 & 397.5 & 268.6 & 10.7 & 18.4 & 30.4 & 63.5 & 22.0 & 9.0 & 31.2 & 73.3 & 258.5 \\
\hline (9) & 1996 & 454.8 & 239.6 & 13.5 & 30.0 & 33.2 & 64.4 & 22.1 & 9.9 & 37.7 & 81.2 & 291.8 \\
\hline (10) & 1997 & 346.3 & 274.1 & 12.3 & 25.8 & 39.5 & 61.2 & 25.0 & 12.2 & 36.7 & 87.0 & 299.6 \\
\hline (11) & 1998 & 439.1 & 208.7 & 11.6 & 23.5 & 37.1 & 61.5 & 19.7 & 10.5 & 29.5 & 83.6 & 277.0 \\
\hline (12) & 1999 & 466.4 & 264.7 & 12.1 & 25.8 & 41.5 & 66.5 & 20.9 & 9.6 & 34.6 & 84.5 & 295.3 \\
\hline (13) & 2000 & 355.1 & 281.1 & 13.2 & 27.4 & 37.8 & 59.5 & 21.7 & 9.9 & 31.5 & 63.9 & 264.9 \\
\hline (14) & 2001 & 326.5 & 214.0 & 11.3 & 26.9 & 37.0 & 61.0 & 21.8 & 10.5 & 29.4 & 63.4 & 261.3 \\
\hline (15) & 2002 & 297.7 & 196.8 & 11.7 & 26.1 & 35.7 & 59.2 & 21.1 & 10.4 & 36.0 & 80.3 & 280.6 \\
\hline (16) & 2003 & 568.1 & 179.4 & 10.9 & 29.2 & 35.6 & 50.5 & 18.7 & 9.6 & 28.3 & 50.6 & 233.3 \\
\hline (17) & 2004 & 400.5 & 342.4 & 10.6 & 29.3 & 37.7 & 56.4 & 20.9 & 10.1 & 26.1 & 49.6 & 240.6 \\
\hline (18) & 2005 & 554.8 & 241.4 & 10.8 & 29.2 & 42.1 & 62.2 & 23.6 & 11.8 & 29.3 & 57.3 & 266.3 \\
\hline (19) & 2006 & 400.2 & 334.4 & 13.6 & 30.1 & 39.0 & 60.9 & 26.8 & 12.9 & 37.8 & 80.5 & 301.6 \\
\hline (20) & 2007 & 489.5 & 241.2 & 13.3 & 30.4 & 39.4 & 59.7 & 25.0 & 13.6 & 33.6 & 71.6 & 286.7 \\
\hline (21) & 2008 & 400.4 & 295.1 & 12.1 & 30.1 & 39.0 & 57.1 & 26.8 & 14.5 & 39.4 & 69.7 & 288.6 \\
\hline (22) & 2009 & 479.9 & 241.4 & 11.0 & 29.9 & 38.0 & 61.3 & 25.6 & 15.1 & 43.4 & 73.4 & 297.7 \\
\hline (23) & 2010 & 457.7 & 289.3 & 10.5 & 30.3 & 35.5 & 61.3 & 24.4 & 18.2 & 44.1 & 74.5 & 298.8 \\
\hline (24) & $\mathrm{CV}$ & 0.20 & 0.20 & 0.14 & 0.14 & 0.09 & 0.07 & 0.12 & 0.19 & 0.17 & 0.22 & 0.09 \\
\hline
\end{tabular}

297 Note: Sichuan province and Tianjin City are not included in the analysis because

298 the water use of Sichuan is much less than the other provinces and no water

299 consumption data are available for Tianjin in some years.

300 Data source: Yellow River Conservation Commission, China

301 The inflow and withdrawal data of St. George under the CS are shown in Table 5.

302 The $\mathrm{CV}$ of total inflows to storage is 0.61 . The $\mathrm{CV}$ of water withdrawals (for

303 irrigation and urban use) is 0.34 .

304 Table 5 annual water availability and use under capacity sharing in St George

305 (Unit: $10^{8} \mathrm{~m}^{3}$ )

\begin{tabular}{ccccccc}
\hline Item & NO. & $\begin{array}{c}\mathbf{2 0 0 4} \text { to } \\
\mathbf{2 0 0 5} \\
(\mathbf{1})\end{array}$ & $\begin{array}{c}\mathbf{2 0 0 5} \text { to } \\
\mathbf{2 0 0 6} \\
(\mathbf{2})\end{array}$ & $\begin{array}{c}\mathbf{2 0 0 6} \text { to } \\
\mathbf{2 0 0 7} \\
\mathbf{( 3 )}\end{array}$ & $\begin{array}{c}\mathbf{2 0 0 7} \text { to } \\
\mathbf{2 0 0 8} \\
(\mathbf{4})\end{array}$ & $\begin{array}{c}\text { CV } \\
(\mathbf{5})\end{array}$ \\
\hline Opening storage volume & $(1)$ & 0.54 & 0.32 & 0.31 & 0.04 & $/$ \\
Total inflows & $(2)$ & 0.71 & 1.11 & 0.13 & 1.11 & 0.61 \\
Storage losses & $(3)$ & 0.36 & 0.41 & 0.13 & 0.36 & $/$ \\
Reconciliation & $(4)$ & 0.11 & 0.06 & 0.06 & 0.07 & $/$ \\
Withdrawals & $(5)$ & 0.68 & 0.76 & 0.33 & 0.50 & 0.34 \\
Total net out flows & $(6)=(5)+(3)-(4)$ & 0.93 & 1.11 & 0.40 & 0.79 & $/$ \\
Est. ending storage volume & $(7)=(1)+(2)-(6)$ & 0.32 & 0.31 & 0.04 & 0.36 & $/$ \\
\hline
\end{tabular}

306 Note: Reconciliation reflects the error of estimation of water losses in the storage

307 and is used to ensure that the volume of water in the storage matches the recorded

308 values in the users' water accounts. 
309 Data source: Australian Bureau of Agricultural and Resource Economics, 2009

310 Table 6 shows the distribution of water-use variability from 2004 to 2008 across

311 the 55 water users in the St. George region. Significant diversity is observed in the

312 variability of individual water use, as proven by the consistent differences in the

313 annual water use strategies adopted by irrigators under the CS. For example,

314 differences between growers of different crops, such as cotton and grapes, and

315 differences in irrigation requirements, are facilitated by CS and thus lead to

316 variation in water-use practices. The diversity of the variability of individual

317 water use is 0.73 , equals to the $\mathrm{CV}$ of the data in column (1) in Table 6 across all

318 the 55 users.

319 Table 6 Water-use diversity among users under capacity sharing

\begin{tabular}{cc}
\hline $\begin{array}{c}\text { Water use variability (coefficient variation), St George } \\
\text { 2002-03 to 2007-08 }\end{array}$ & Percentage of users \\
\hline 0.0 & 0.0 \\
$0.0-0.2$ & 6.8 \\
$0.2-0.4$ & 28.8 \\
$0.4-0.6$ & 27.7 \\
$0.6-0.8$ & 8.8 \\
$0.8-1.0$ & 4.0 \\
$1.0-1.2$ & 6.6 \\
$1.2-1.4$ & 6.6 \\
$1.4-1.6$ & 4.5 \\
$1.6-1.8$ & 2.0 \\
$1.8-2.0$ & 0.0 \\
$2.0-2.2$ & 4.2 \\
\hline
\end{tabular}

320 Data source: Australian Bureau of Agricultural and Resource Economics, 2009

321 The natural runoff and water-use data in the Taolai RB under the duration-based

322 allocation regime are shown in Table 7 . The annual water allocations among the

323 irrigation regions are estimated by integrating the river flow across all the

324 allocation periods of the irrigation regions. The CV of annual water allotment,

325 which represents the variation of the water availability, is 0.18 . The water use (for

326 irrigation and urban use) CV of Taolai and Yuanyang irrigation regions are 0.07

327 and 0.28 , across which the diversity is estimated at 0.87 .

328 Table 7 Annual water allotment and use in Taolai River Basin under duration-

329 based allocation (Unit: $10^{8} \mathrm{~m}^{3}$ )

\begin{tabular}{|c|c|c|c|c|c|c|c|c|}
\hline \multirow{2}{*}{ No. } & \multirow{2}{*}{ Year } & \multirow{2}{*}{$\begin{array}{c}\text { Natural } \\
\text { runoff } \\
(1)\end{array}$} & \multicolumn{3}{|c|}{ Annual water allotment } & \multicolumn{3}{|c|}{ Water use } \\
\hline & & & $\begin{array}{c}\text { Taolai } \\
(2)\end{array}$ & $\begin{array}{c}\text { Yuanyang } \\
\text { (3) }\end{array}$ & $\begin{array}{c}\text { Total } \\
(4)=(2)+(3)\end{array}$ & $\begin{array}{c}\text { Taolai } \\
(4) \\
\end{array}$ & $\begin{array}{c}\text { Yuanyang } \\
(5) \\
\end{array}$ & $\begin{array}{c}\text { Total } \\
(6)=(4)+(5)\end{array}$ \\
\hline$(1)$ & 1980 & 5.67 & 2.13 & 1.95 & 4.08 & 1.55 & 1.95 & 3.50 \\
\hline$(2)$ & 1981 & 7.32 & 3.35 & 3.10 & 6.45 & 1.79 & 4.19 & 5.98 \\
\hline (3) & 1982 & 6.13 & 2.96 & 2.53 & 5.49 & 1.76 & 3.08 & 4.84 \\
\hline & & & & & & & & 13 \\
\hline
\end{tabular}




\begin{tabular}{|c|c|c|c|c|c|c|c|c|}
\hline \multirow{2}{*}{ No. } & \multirow{2}{*}{ Year } & \multirow{2}{*}{$\begin{array}{c}\text { Natural } \\
\text { runoff } \\
\text { (1) }\end{array}$} & \multicolumn{3}{|c|}{ Annual water allotment } & \multicolumn{3}{|c|}{ Water use } \\
\hline & & & $\begin{array}{c}\text { Taolai } \\
(2) \\
\end{array}$ & $\begin{array}{c}\text { Yuanyang } \\
(3)\end{array}$ & $\begin{array}{c}\text { Total } \\
(4)=(2)+(3)\end{array}$ & $\begin{array}{c}\text { Taolai } \\
(4) \\
\end{array}$ & $\begin{array}{c}\text { Yuanyang } \\
(5)\end{array}$ & $\begin{array}{c}\text { Total } \\
(6)=(4)+(5)\end{array}$ \\
\hline (4) & 1983 & 7.02 & 3.36 & 3.05 & 6.41 & 1.72 & 3.74 & 5.46 \\
\hline$(5)$ & 1984 & 5.21 & 2.36 & 2.08 & 4.44 & 1.54 & 1.95 & 3.49 \\
\hline (6) & 1985 & 5.14 & 1.98 & 1.81 & 3.79 & 1.65 & 1.80 & 3.45 \\
\hline (7) & 1986 & 5.37 & 2.12 & 1.88 & 4.00 & 1.57 & 1.92 & 3.50 \\
\hline$(8)$ & 1987 & 5.57 & 2.52 & 1.93 & 4.46 & 1.59 & 1.74 & 3.33 \\
\hline$(9)$ & 1988 & 4.68 & 1.96 & 1.93 & 3.89 & 1.55 & 1.87 & 3.41 \\
\hline (10) & 1989 & 4.69 & 3.15 & 2.66 & 5.81 & 1.80 & 3.48 & 5.28 \\
\hline (11) & 1990 & 4.47 & 2.09 & 2.14 & 4.23 & 1.56 & 2.33 & 3.89 \\
\hline (12) & 1991 & 5.08 & 2.07 & 1.95 & 4.01 & 1.49 & 1.95 & 3.44 \\
\hline (13) & 1992 & 5.14 & 2.29 & 2.21 & 4.50 & 1.58 & 2.48 & 4.06 \\
\hline (14) & 1993 & 5.29 & 2.63 & 2.47 & 5.11 & 1.65 & 2.86 & 4.51 \\
\hline (15) & 1994 & 5.16 & 2.39 & 2.14 & 4.53 & 1.65 & 3.37 & 5.01 \\
\hline (16) & 1995 & 5.59 & 2.09 & 1.91 & 4.00 & 1.48 & 2.00 & 3.48 \\
\hline (17) & 1996 & 4.82 & 2.07 & 2.07 & 4.14 & 1.44 & 2.31 & 3.75 \\
\hline (18) & 1997 & 4.41 & 1.79 & 1.72 & 3.51 & 1.48 & 1.66 & 3.14 \\
\hline (19) & 1998 & 5.58 & 2.57 & 2.40 & 4.96 & 1.69 & 2.78 & 4.47 \\
\hline (20) & 1999 & 6.70 & 2.79 & 2.76 & 5.55 & 1.65 & 3.36 & 5.01 \\
\hline (21) & 2000 & 6.39 & 3.02 & 2.72 & 5.74 & 1.64 & 3.47 & 5.10 \\
\hline (22) & 2001 & 5.86 & 2.43 & 2.24 & 4.66 & 1.59 & 2.51 & 4.10 \\
\hline (23) & 2002 & 6.54 & 3.17 & 3.01 & 6.18 & 1.37 & 3.88 & 5.26 \\
\hline (24) & 2003 & 5.71 & 2.28 & 2.22 & 4.50 & 1.63 & 2.39 & 4.02 \\
\hline (25) & 2004 & 5.98 & 2.34 & 2.15 & 4.49 & 1.65 & 2.22 & 3.87 \\
\hline (26) & 2005 & 7.08 & 3.08 & 2.87 & 5.95 & 1.75 & 3.41 & 5.16 \\
\hline (27) & 2006 & 6.48 & 2.56 & 2.53 & 5.09 & 1.69 & 2.84 & 4.54 \\
\hline (28) & 2007 & 7.39 & 3.21 & 2.92 & 6.13 & 1.80 & 3.92 & 5.72 \\
\hline (29) & 2008 & 6.31 & 2.64 & 2.66 & 5.30 & 1.69 & 3.18 & 4.88 \\
\hline (30) & $\mathrm{CV}$ & 0.15 & 0.18 & 0.18 & 0.18 & 0.07 & 0.28 & 0.19 \\
\hline
\end{tabular}

330 Note: the annual water use of JQI\&SC is limited to 37 days and also 45 million

$331 \mathrm{~m}^{3}$; thus, it was not considered in the assessment.

332 Data source: Water Resources Management Bureau of Taolai RB, China

333 Table 8 shows the flexibility based performance of the three water allocation

334 regimes. DWA regime is estimated to have the highest flexibility in terms of

335 water use. SWA in the Yellow RB has the lowest flexibility compared with the

336 other two allocation regimes.

337 Table 8 Flexibility of water allocation regimes

\begin{tabular}{cccccc}
\hline $\begin{array}{c}\text { Water allocation } \\
\text { regime }\end{array}$ & $\begin{array}{c}\text { Variability of } \\
\text { allotment } \\
(\mathbf{1})\end{array}$ & $\begin{array}{c}\text { Variability } \\
\text { of use } \\
\mathbf{( 2 )}\end{array}$ & $\begin{array}{c}\text { Diversity of } \\
\text { use } \\
\mathbf{( 3 )}\end{array}$ & Flexibility \\
\hline SWA & $(1)$ & 0.20 & 0.09 & 0.35 & 0.16 \\
CS & $(2)$ & 0.61 & 0.34 & 0.73 & 0.41 \\
DWA & $(3)$ & 0.18 & 0.19 & 0.87 & 0.92 \\
\hline Note: [row (1), column (1)] = [row (24), column (1)] in Table 4; [row (1), column (2)] = [row (24),
\end{tabular}

338 Note: [row (1), column (1)] = [row (24), column (1)] in Table 4; [row (1), column (2)] = [row (24),

339 column (11)] in Table 4. [row (2), column (1)] = [row (2), column (5)] in Table 5; [row (2),

340 column (2)] $=$ [row (5), column (5)] in Table 5. [row (3), column (1)] = [row (30), column (4)] in

341 Table 7; [row (3), column (2)] = [row (30), column (6)] in Table 7. 


\section{Discussion}

343 Under the SAW, users' annual mean water rights are defined by volumetrically

344 sharing the annual mean runoff of a river. The water management authority

345 announces the available percentage of the annual mean water right at the start of

346 the season to each individual user according to the forecasted stream flow and

347 current storage. Given the uncertainty over seasonal inflows, allocations are

348 announced and progressively adjusted, often at monthly intervals. Typically, the

349 initial allocation at the commencement of the season is relatively conservative,

350 and the allocation is increased or reduced as inflows arrive later in the season

351 (Hughes and Goesch 2009b) under a centralized regulation regime.

$352 \mathrm{CS}$ is a more decentralized process that allows individual users to exercise a 353 certain degree of individual control over storage decisions, leading to more

354 flexible management of water. As a result, water entitlements closely reflect the 355 physical realities of the water supply system, such as constrained storage capacity, 356 variable water inflows, and significant losses from storage and delivery.

357 The DWA system is simpler than the CS and allows individual water users to 358 withdraw and store the entire natural stream flow within their permitted extraction 359 period and independently manage it. Users can decide how much water to use and 360 how much to leave in the water course while taking all risks from hydrological 361 uncertainty. The water authority does not need to make volumetric allocation 362 announcements, and is only responsible for water-use planning and accounting to 363 ensure that water users do not exceed their allotted duration. The hydrological 364 risks are shouldered by the water users, but they also acquire more flexibility to 365 make their own decisions on use.

366 Our assessment results show that the water-use flexibility under DWA is higher 367 than that of CS. The reason for this finding is that users can freely withdraw water 368 from the river course during their allocation periods without reservoir regulation 369 in the DWA. As there are less reservoirs in the Taolai RB, the water users highly 370 rely on the stream inflow. People have to adjust the their water demand if there is 371 a water deficit. For example, the local farmers accept to reduce irrigation water or 372 cancel some irrigation plans to some extent if there is insufficient water in the 373 river during their allocation periods. Farmers tend to regard this water shortage as 374 "acceptable", because the deficit is caused by the natural hydrological variability 
375 and they unfortunately encounter a drought during their allocation periods. This

376 behavior increase the flexibility in the basin.

377 It may be argued that the degree of water use flexibility in the St. George, where

378 the runoff is nearly thoroughly regulated by a multiyear reservoir, should be the

379 highest. This is because that the runoff regulation reservoirs play an critical role in

380 flexible water use. With enough reservoirs, users can withdraw water from storage

381 at almost any time when their need it. This increases the water supply reliability

382 and use flexibility. However, in the Taolai RB which actually is surrounded by

383 deserts and has a lot of potential farm lands, the water users are able to pump all

384 the stream water for irrigation from the river during their allocation periods and

385 can reduce the water demand when drought. The elastic demand management

386 strategy under the DWA allows the Taolai RB have higher degree of flexibility

387 even its runoff is partly regulated.

388 The disadvantage of DWA is also obvious. Considering that no volumetric caps in 389 water use or requirements of environmental flow maintenance exist, DWA system

390 often results in the drying up of surface stream and the over-extraction of ground

391 water. The surface water resources development ratio of the Taolai River has been

392 rising and is now close to $100 \%$; the groundwater has also been over-exploited.

393 Although these problems could be remedied using a western style approach to

394 volumetric water licensing, or by allowing water abstractions only when river

395 flows are above pre-determined levels such as the regimes used in the southern

396 Murray Darling Basin in unregulated streams (Goulburn Murray Water, 2013).

397 Referring to the formula of $\boldsymbol{F}$, the $\boldsymbol{W A}(t)$ is recognized as the maximum water 398 volume that people are able to harvest and withdraw from the river in the basin.

399 This water availability cannot always fully meet the demand, especially in the arid

400 areas. In the Taolai RB and the Yellow RB, due to the development of agriculture

401 and the dry climate, there are plenty of irrigation districts which are able to

402 consume all the stream flow and dry up the river if there are no water use

403 permission systems. In this case, the water availability is limited by the quantity

404 of natural water resource and is equal to the runoff.

405 The case study areas adopted in this study obviously vary in terms of natural and 406 social backgrounds, such as the precipitation, degree of regulation, scale of 407 agriculture, aquatic environment conditions, environmental water allocation and 
408 farmers' income influenced by market conditions (crop prices and agricultural 409 costs) as well as the number of water users in a system, etc. These differences 410 could influence the variation and diversity in surface water use. For example, The 411 annual mean rainfall in St George, is about $530 \mathrm{~mm}$ which is higher than that in

412 the Yellow RB, at $430 \mathrm{~mm}$ and in the Taolai RB, at about $80 \mathrm{~mm}$. This means that

413 water famers in the St George may less rely on the stream water for irrigation and 414 need more autonomous water use strategy. In addition, the Australian farmers 415 who generally have much larger land area than the Chinese ones, can make 416 more wealth from irrigation agriculture and be richer. This may provide the 417 Australian farmers with stronger capability to develop individual water use 418 strategy, such as selling water to others in a high price. However, this paper 419 focuses on proposing a method for orienting assessments about the flexibility of 420 the basin overall management system. It gives an averaged estimation. Future 421 research to develop a practical system to underpin policy and decision making 422 should investigate the detail and significance of factors that might influence water 423 use variability and diversity.

\section{Conclusion}

425 River flow is characterized by variability and research has demonstrated that 426 flexible water allocation systems substantially improve regional welfare (Kilgour 427 and Dinar 2001). Understanding and increasing the flexibility of water allocation 428 systems to cope with hydrologic variability is one of the key issues in sustainable 429 water management.

430 This study proposes a quantitative method to measure water allocation flexibility. 431 Results show that water allocation flexibility is positively correlated with water 432 use autonomy. Evidence from the comparative study among the SWA in the 433 Yellow River in China, the CS in Australia, and the DWA in Northwestern China 434 shows that the more choices or the higher capacity for autonomous water use 435 allocated to distributive water users, the greater the flexibility obtained by the 436 allocation system. The proposed method could provide a comparative reference 437 for different water allocation regimes based on the performance of flexibility and 438 help in quantitatively identifying key factors, such as autonomy, diversity, and 439 variability, which can improve the flexibility level of the water allocation system. 
440 The proposed method is also useful for evaluating and developing water

441 allocation regimes with more flexibility.

442

443

Acknowledgement

444 This research was supported by the National Natural Science Foundation of China

445 (91125018 and 51009076), the 2012 Chinese Ministry of Science and Technical-

446 Internet of Water Project (2013BAB05B03), the 2011 Chinese Ministry of Water

447 Resource Program-Shiyang River Project (201101046), and the Australian

448 Research Council (Project No. DP120102917).

449

Reference

Assche VK, Beunen R, Jacobs J, Teampau P (2012) Crossing trails in the marshes: rigidity and flexibility in the governance of the Danube Delta. Journal of Environmental Planning and Management 54(8): 997-1018.

Cross P (2000) Benefits of flexible Irrigation water supply. Journal of Irrigation and Drainage Engineering 126(5): 275-278

Dudley N, Musgrave W (1988) Capacity sharing of water reservoirs. Water Resources Research 24(5): 649-658

Falkenmark M, Rockström J (2010) Building Water Resilience in the Face of Global Change: From a Blue-Only to a Green-Blue Water Approach to Land-Water Management. Journal of Water Resources Planning and Management 136(6): 606-610

Faye RM, Sawadogo S, Mora-Camino F (2005) Flexible management of water resource systems. Applied Mathematics and Computation 167(1): 516-527

Goulburn Murray Water (2013) Unregulated Streams Local Management Rules. http://www.g-mwater.com.au/water-resources/surface-water/unregulatedlocal-management-rules.

Graddon AR, Kuczera G, Hardy MJ (2011) A flexible modelling environment for integrated urban water harvesting and re-use. Water Science \& Technology 63(10): 2268-2278

Grönlund E, Määttä T (2008) Implications of flexibility in European Community environmental law: exemptions from environmental objectives in the Water Framework Directive. Hydrobiologia 599(1): 221-226

Gunderson LH, Carpenter SR, Folke C, Olsson P, Peterson GD (2006) Water RATs (resilience,adaptability, and transformability) in lake and wetland social-ecological systems. Ecology and Society 11(1): 16

Gupta D, Buzacott JA (1989) A framework for understanding flexibility of manufacturing systems. Journal of Manufacturing Systems 8(2): 89-97

Hughes N, Goesch T (2009a) Management of irrigation water storages: carryover rights and capacity sharing. Australian Bureau of Agricultural and Resource Economics, research report 09.10, Canberra, May.

Hughes N, Goesch T (2009b) Capacity sharing in the St George and MacIntyre Brook irrigation schemes in southern Queensland. Australian Bureau of 
Agricultural and Resource Economics, research report 09.12, Canberra, June.

Jafarzadegan K, Abed-Elmdoust A, Kerachian R (2013) A fuzzy variable least core game for inter-basin water resources allocation under uncertainty. Water Resources Management 27(9): 3247-3260.

Kilgour D, Dinar A (2001) Flexible water sharing within an international river basin. Environmental and Resource Economics 18(1): 43-60.

Kumar V (1987) Entropic measures of manufacturing flexibility. International Journal of Production Research 25(7): 957-966.

Larsen TA, Gujer W (2001) Waste design and source control lead to flexibility in wastewater management. Water Science and Technology 43(5): 309-318.

Li BH, Chang CT (2011) Efficient flexibility assessment procedure for water network designs. Industrial \& Engineering Chemistry Research 50(7): 3763-3774.

Marreco J, Carpio L (2006) Flexibility valuation in the Brazilian power system: A real options approach. Energy Policy 34(8): 3749-3756.

Milman A, Short A (2008) Incorporating resilience into sustainability indicators: An example for the urban water sector. Global Environmental Change 18(4): 758-767.

Schlüter M, Pahl-Wostl C (2007) Mechanisms of resilience in common-pool resource management systems: an agent-based model of water use in a river basin. Ecology and Society 12(2): 4.

Shao WW, Yang DW, Hu HP, Sanbongi K (2009) Water resources allocation considering the water use flexible limit to water shortage - a case study in the Yellow River Basin of China. Water Resource Manage 23(5): 869-880.

Shuiabia E, Thomsona V, Bhuiyanb N (2005) Entropy as a measure of operational flexibility. European Journal of Operational Research 165(3): 696-707.

Teh CL, Teh SL, Meitner JM (2012) Preferred resource spaces and fisher flexibility: implications for spatial management of small-scale fisheries. Human Ecology 40(2): 213-226.

Wang ZJ, Zheng H, Wang X (2009) A harmonious water rights allocation model for Shiyang River Basin, Gansu Province, China. International Journal of Water Resources Development 25(2): 355-370.

Wright TF, Eberhard JR, Hobson EA, Avery ML, Russell MA (2010) Behavioral flexibility and species invasions: the adaptive flexibility hypothesis. Ethology Ecology and Evolution 22(4): 393-404.

Xia C, Pahl-Wostl C (2012) The development of water allocation management in the Yellow River Basin. Water Resources Management 26(3): 395-3414.

Yang D, Li C, Hu H, Lei Z, Yang S, Kusuda T, Koike T, Musiake K (2004) Analysis of water resources variability in the Yellow River of China during the last half century using historical data. Water Resources Research 40:W06502.

YRCC (2008) Management and diversion of water resources in the Yellow River. The Yellow River Publisher, Zhengzhou, China.

Zheng H, Wang ZJ, Hu SY, Malano H (2013) Seasonal water allocation - dealing with hydrologic variability in the context of water rights system. Journal of Water Resources Planning and Management, 139(1), 76-85.

Zheng H, Wang ZJ, Hu SY, Wei YP (2012) A comparative study of the performance of public water rights allocation in China. Water Resources Management 26(5): 1107-1123. 


\section{University Library}

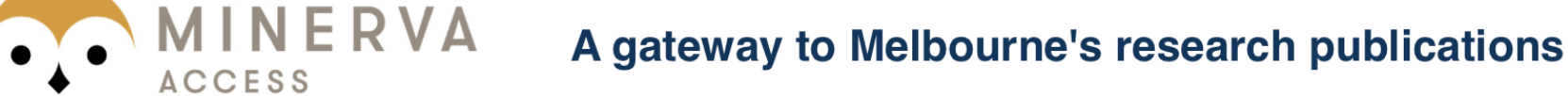

Minerva Access is the Institutional Repository of The University of Melbourne

Author/s:

Zheng, H;Lyle, C;Wang, Z

Title:

A Comparative Study of Flexibility in Water Allocation in the Context of Hydrologic Variability

Date:

2014-02-01

Citation:

Zheng, H., Lyle, C. \& Wang, Z. (2014). A Comparative Study of Flexibility in Water Allocation in the Context of Hydrologic Variability. WATER RESOURCES MANAGEMENT, 28 (3),

pp.785-800. https://doi.org/10.1007/s11269-014-0515-4.

Persistent Link:

http://hdl.handle.net/11343/283322 